\title{
Olig Transcription Factors Are Expressed in Oligodendrocyte and Neuronal Cells in Human Fetal CNS
}

\author{
Igor Jakovcevski and Nada Zecevic \\ Department of Neuroscience, University of Connecticut Health Center, Farmington, Connecticut 06030
}

\begin{abstract}
The transcription factors Olig1 and Olig2 are closely associated with the development of oligodendrocyte (OL) lineage in the vertebrate nervous system, but little is known about their role in the human developing CNS. To test the hypothesis that they contribute to initial OL specification in humans, we studied the expression of Olig1 and 0lig2 in human fetuses at 5-24 gestational weeks (GW). Both transcription factors were present in well outlined regions of the ventral neuroepithelium at $5 \mathrm{GW}$, several weeks before oligodendrogenesis. Spatial differences in the expression of Olig1 and Olig2 along the neuronal axis suggest that they specify different subpopulations of progenitor cells. Olig1 was distributed rostrally, from the basal forebrain to the hindbrain, whereas Olig2 was also found in the ventral spinal cord. Furthermore, at $5 \mathrm{GW}$, Olig1 was coexpressed with vimentin, and Olig2 was coexpressed with a neuronal marker, microtubule-associated protein 2 . With the progression of development at $15 \mathrm{GW}$, both proteins were present throughout the spinal cord and the ventricular-subventricular zone of the ganglionic eminences, whereas at midgestation $(20 \mathrm{GW})$, they were also expressed in the telencephalic proliferative zones and the emerging white matter. Double-labeling studies revealed that early OL progenitor cells and radial glia expressed Olig1, whereas Olig2 was localized predominantly in mature OLs and a subset of neural progenitor cells and mature neurons. Thus, Olig1 and Olig2 transcription factors in the human CNS are important not only for differentiation of the OL lineage, but they may also have a role in neural cell specification.
\end{abstract}

Key words: oligodendrocyte progenitors; human embryo; fetus; human brain development; immunohistochemistry; common progenitors; transcription factors

\section{Introduction}

The specification of different cell types in the nervous system is regulated by the precise spatiotemporal expression of particular genes (Jessell, 2000; Miller, 2002; Rowitch, 2004), which results in a sequential generation of neurons, oligodendrocytes (OLs), and astrocytes (Sidman and Rakic, 1982; Altman and Bayer, 1984).

In rodents, oligodendrogenesis starts ventrally and depends on signaling by sonic-hedgehog (Shh), which influences Olig1 and Olig2 expression, and the generation of OLs in both the spinal cord (Orentas and Miller, 1996; Lu et al., 2000; Richardson et al., 2000; Spassky et al., 2000; Takebayashi et al., 2000; Zhou et al., 2000) and ventral telencephalon (Nery et al., 2001; TekkiKessaris et al., 2001). Olig1 and Olig2 are basic helix-loop-helix transcription factors that have been described initially in the ven-

Received June 7, 2005; revised Sept. 13, 2005; accepted Sept. 17, 2005.

This work was supported by National Institutes of Health Grant NS 41489 and Society for Multiple Sclerosis Grant RG 3083 B3/1. We thank Drs. C. D. Stiles and D. H. Rowitch (Harvard Medical School, Boston, MA) for Olig1 and 0lig2 antibodies and RNA probes. We also thank W. B. Stallcup (The Burnham Institute, La Jolla, CA), M. Tosic (University of Lausanne, Lausanne, Switzerland), and M. Ogawa (Kochi Medical School, Kochi, Japan) for generous gifts of antibodies; Dr. Y. Kaga and Mihaela Anitei for help with the in situ hybridization and Western blot experiments; Dr. S. E. Pfeiffer for antibodies and for critically reviewing a previous version of this manuscript; and Brian Howard for editing the English (all from the University of Connecticut Medical School, Farmington, CT). Midgestational human tissue was obtained from Dr. B. Poulos (Albert Einstein College of Medicine, Bronx, NY).

Correspondence should be addressed to Dr. Nada Zecevic, University of Connecticut Health Center, 263 Farmington Avenue, Farmington, CT 06030-3401. E-mail: nzecevi@@neuron.uchc.edu.

I. Jakovcevski's present address: Center for Molecular Neuroscience, University of Hamburg, D-20246 Hamburg, Germany.

D01:10.1523/JNEUROSCI.2324-05.2005

Copyright $\odot 2005$ Society for Neuroscience 0270-6474/05/2510064-10\$15.00/0 tral spinal cord in a subpopulation of neural progenitors ( $\mathrm{pMN}$ ) that give rise first to motor neurons (MNs) and then OLs ( $\mathrm{Lu}$ et al., 2000, 2002; Takebayashi et al., 2000; Zhou et al., 2000). Both gain-of-function and loss-of-function studies confirmed that olig genes are necessary and sufficient for the generation of OLs and myelination (Lu et al., 2000, 2002; Zhou et al., 2000, 2001; TekkiKessaris et al., 2001; Takebayashi et al., 2002; Zhou and Anderson, 2002; Xin et al., 2005).

In the human brain, Olig1 and Olig2 are demonstrated in adult white matter (Arnett et al., 2004) and in gliomas, which are subtypes of primary brain tumors (Lu et al., 2001; Hoang-Xuan et al., 2002; Bouvier et al., 2003; Ligon et al., 2004). Knowledge of their temporal and spatial distribution might be important for understanding the specification of neuroepithelial cells into cells of OL lineage; however, neither Olig1 nor Olig2 has been studied during human brain development.

Along with other groups, we previously described the differentiation of OLs in the human fetal telencephalon (Rivkin et al., 1995; Back et al., 2001; Ulfig et al., 2002; Rakic and Zecevic, 2003; Jakovcevski and Zecevic, 2005). Telencephalic OLs are derived from cortical and ganglionic eminence (GE) subventricular zones (SVZs) (Ulfig et al., 2002; Rakic and Zecevic, 2003). In animal models, the medial GE (MGE) is a major source of telencephalic OLs (Spassky et al., 1998; Sussel et al., 1999; He et al., 2001; Marshal and Goldman, 2002); however, initial OL specification is not well understood, either in animal models or in the human brain. In this study, we examine whether the expression of 
Table 1. Human fetal brains used in this study

\begin{tabular}{|c|c|c|c|c|}
\hline Case number & Gender & Gestation weeks & Sections & Cell culture \\
\hline 1 & $?$ & $5(16)$ & + & \\
\hline 2 & $?$ & $5.5(17)$ & + & \\
\hline 3 & $?$ & 9 & + & \\
\hline 4 & $?$ & 10 & + & \\
\hline 5 & $\mathrm{~F}$ & 15 & + & \\
\hline 6 & $\mathrm{~F}$ & 18 & + & \\
\hline 7 & $\mathrm{~F}$ & 19 & & WB+ \\
\hline 8 & M & 19 & & + \\
\hline 9 & M & 19 & + & \\
\hline 10 & $\mathrm{~F}$ & 20 & + & \\
\hline 11 & M & 22 & + & WB+ \\
\hline 12 & $\mathrm{~F}$ & 22 & + & \\
\hline 13 & $\mathrm{~F}$ & 22 & + & + \\
\hline 14 & $\mathrm{~F}$ & 22 & + & \\
\hline 15 & M & 23 & + & \\
\hline 16 & M & 23 & + & \\
\hline 17 & M & 23 & & + \\
\hline 18 & $\mathrm{~F}$ & 24 & + & + \\
\hline
\end{tabular}

Carnegie stages are in parentheses. F, Female; M, male; WB, Western blot.

Olig1 and Olig2 transcription factors coincides spatiotemporally with the onset and developmental progression of OL lineage in the human fetal CNS.

We demonstrate that olig genes are well conserved during evolution and are present in the human brain from early stages of development. The expression of both proteins precedes identification of early OL progenitors, but over the subsequent several months, Olig1 and Olig2 are expressed at various stages along the OL lineage, both in the spinal cord and in the forebrain. In addition, Olig1 is present in radial glia (RG) cells, which are precursors of cortical projection neurons (Noctor et al., 2001), whereas Olig2 is found in a subpopulation of neurons and nestin ${ }^{+}$cells. Spatiotemporal differences in the onset of their expression suggest that olig genes are important not only for initial OL specification, but also for the development of other neural cell types.

\section{Materials and Methods}

Tissue. Human fetuses (5-24 GW; $n=18$ ) (Table 1) were obtained after legal abortions performed at the Obstetrics and Gynecology Clinic, University of Belgrade (Serbia), and from the Brain Bank, Albert Einstein College of Medicine (Bronx, NY). The Institutional Ethics Committees of the University of Belgrade, Albert Einstein College of Medicine, and the University of Connecticut approved the tissue collection, and informed consent was obtained from the parents. The handling of tissue was performed in accordance with all regulations set forth by the Institutional Ethics Committees and the Helsinki Convention. No evidence of disease or developmental abnormalities was discovered after ultrasonic and neuropathological examination. The time between the abortion and the fixation of the collected tissue was $15 \mathrm{~min}$ on average. The ages of the embryos and fetuses were estimated on the basis of weeks after ovulation, crown-rump length (Olivier and Pineau, 1962), and anatomical landmarks (O’Rahilly et al., 1987).

Tissue was fixed in $4 \%$ paraformaldehyde (PFA) in $0.1 \mathrm{~m}$ phosphate buffer, cryoprotected by immersion in 30\% sucrose, and frozen in isopentane cooled to $-70^{\circ} \mathrm{C}$. Frozen tissue was cut into $15-\mu \mathrm{m}$-thick sections for immunohistochemistry. For immunofluorescence with antiGABA antibody, tissue was fixed with $4 \%$ PFA and $0.2 \%$ glutaraldehyde.

Acutely dissociated VZ-SVZ cell culture. To study and quantify proliferation of Olig2 ${ }^{+}$cells, we established an acute cell culture of the VZSVZ region of the fetal brain. We used a protocol similar to that described by Hartfuss et al. (2001): human fetal brains (19-24 GW; $n=5$ ) were sectioned into $1 \mathrm{~cm}$ coronal slices in cold HBSS. The texture of the VZ-SVZ on these slices looked different under the dissecting microscope, and it was possible to separate the tissue band $\sim 2000 \mu \mathrm{m}$ above the VZ surface to include the VZ-SVZ and a small part of the intermediate zone. Tissue was stored in HBSS (Sigma, St. Louis, MO) on ice, trypsinized, and resuspended in DMEM (Sigma) containing $3.7 \mathrm{~g} / \mathrm{L}$ $\mathrm{NaHCO}_{3}, 10 \%$ bovine growth serum (Hyclone, Logan, UT), $2 \mathrm{~mm}$ L-glutamine (Invitrogen, Carlsbad, CA), and antibiotics-antimycotics (2000 U penicillin, $2000 \mu \mathrm{g} / \mathrm{ml}$ streptomycin sulfate, and $0.5 \mu \mathrm{g} / \mathrm{ml} \mathrm{am-}$ fotericin B) (Invitrogen). Cells were plated at a concentration of $1 \times 10^{5}$ cells per well and allowed to adhere to poly-L-lysine-coated dishes, incubated for $4 \mathrm{~h}$, and then fixed with $4 \%$ PFA for $30 \mathrm{~min}$. The total number of viable cells, assessed by trypan blue exclusion, was $90.8 \pm 8.5 \%$.

Bromodeoxyuridine labeling. The thymidine analog 5-bromodeoxyuridine (BrdU) was added in a dose of $25 \mu \mathrm{M}$ to dissociated cell cultures for $4 \mathrm{~h}$. Then cells were fixed in a mixture of ethanol and glacial acid (95:5), denaturated in $2 \mathrm{~N} \mathrm{HCl}$, and incubated with sodium borate buffer $(0.1 \mathrm{M}), \mathrm{pH} 8.5$, for $10 \mathrm{~min}$. Mouse monoclonal anti-BrdU antibody [Becton Dickinson (Mountain View, CA) or Fitzgerald Industries (Concord, MA)] diluted 1:50 in PBS containing 3\% normal goat serum was added overnight. After sections were rinsed, they were incubated for $2 \mathrm{~h}$ at room temperature with secondary antibody (1:400; Alexa Fluor 555; Invitrogen, Eugene, OR) and coverslipped with Vectashield (Vector Laboratories, Burlingame, CA).

Immunofluorescence. Various primary antibodies and corresponding fluorescein- and rhodamine-conjugated secondary antibodies (Jackson ImmunoResearch, West Grove, PA) were used (see below). Sections were viewed with an LSM 410 confocal laser-scanning microscope (Zeiss, Oberkochen, Germany). Three-dimensional reconstructions were done with Imaris 3D software (Bitplane, Zurich, Switzerland).

In situ hybridization. Digoxigenin was used to label RNA probes for Olig1 and Olig2 that were cloned on the basis of the GenBank published sequences AP000109 and Q13516, respectively (Lu et al., 2001). Protocol for the in situ hybridization was similar to the one published previously (Bansal et al., 2003). Sections were kept overnight at $65^{\circ} \mathrm{C}$ in hybridization solution containing $50 \%$ formamide, $4 \times$ SSC, and $1 \%$ SDS. After rinses in SSC, alkaline phosphatase-conjugated anti-digoxigenin antibody (Roche, Nutley, NJ) was used at 1:5000 dilution in Tris-buffered solution with $1 \%$ normal goat serum. Visualization of the enzyme-substrate reaction was done in nitroblue-tetrazolium-chloride/5-bromo-4chloro-3-indolyl-phosphate (Roche).

Western blot analysis. Brain slices from 19 and $22 \mathrm{GW}$ fetuses were dissected through the parietal lobe, and tissue samples designated as VZ, SVZ, white matter, and cortical plate were homogenized in a glass homogenizer in radioimmunoprecipitation assay buffer with protease inhibitors and sonicated for $1 \mathrm{~min}$. Homogenates were centrifuged for 5 min at $6000 \times g$ to separate the nuclear (pellet) and postnuclear (supernatant) fractions. Pellets were resolubilized, run on SDS-PAGE, and transferred to a nitrocellulose membrane (Hyperbond P; Amersham Biosciences, Piscataway, NJ). Membranes were blocked with $5 \%$ nonfat milk in $0.5 \%$ Tween $20, \mathrm{pH} 7.6$, and incubated overnight at $4^{\circ} \mathrm{C}$ with primary antibodies (Olig1, 1:15,000; Olig2, 1:20,000), followed by incubation for $30 \mathrm{~min}$ at room temperature with a secondary antibody (horseradish peroxidase donkey anti-rabbit IgG, 1:10,000). The signal was detected by enhanced chemiluminescence (Amersham Biosciences).

Antibodies. Olig1 and Olig2 antibodies were a gift from Dr. C. D. Stiles, Harvard Medical School, Boston, MA [rabbit, 1:5000 and 1:10,000, respectively (Arnett et al., 2004)]. OL progenitor cells were labeled with antibodies against platelet-derived growth factor receptor- $\alpha$ (PDGFR- $\alpha$ ) [mouse, 1:25; PharMingen, San Diego, CA (Lu et al., 2000)], NG2 [rabbit, 1:100; Chemicon, Temecula, CA (Stallcup and Beasley, 1987)], and $\mathrm{O} 4$ and $\mathrm{O} 1$ antibodies [mouse, 1:5 and 1:25, respectively; gift from Dr. S. E. Pfeiffer, University of Connecticut (Sommer and Schachner, 1981)]. OLs were labeled with antibody to myelin basic protein (MBP) [mouse, SMI-99, 1:100; Sternberger Monoclonals, Lutherville, MD (Weidenheim et al., 1992)] and proteolipid protein (PLP)-DM20 [rabbit, 1:500; gift from Dr. M. Tosic, University of Lausanne, Lausanne, Switzerland (Timsit et al., 1992)]. A positive immunoreaction in all cases was accompanied by typical morphology described previously for cells of OL lineage (Pfeiffer et al., 1993).

Neurons were labeled with monoclonal (mouse) antibodies to microtubule-associated protein 2 (MAP2) (1:200; Sigma), phosphory- 

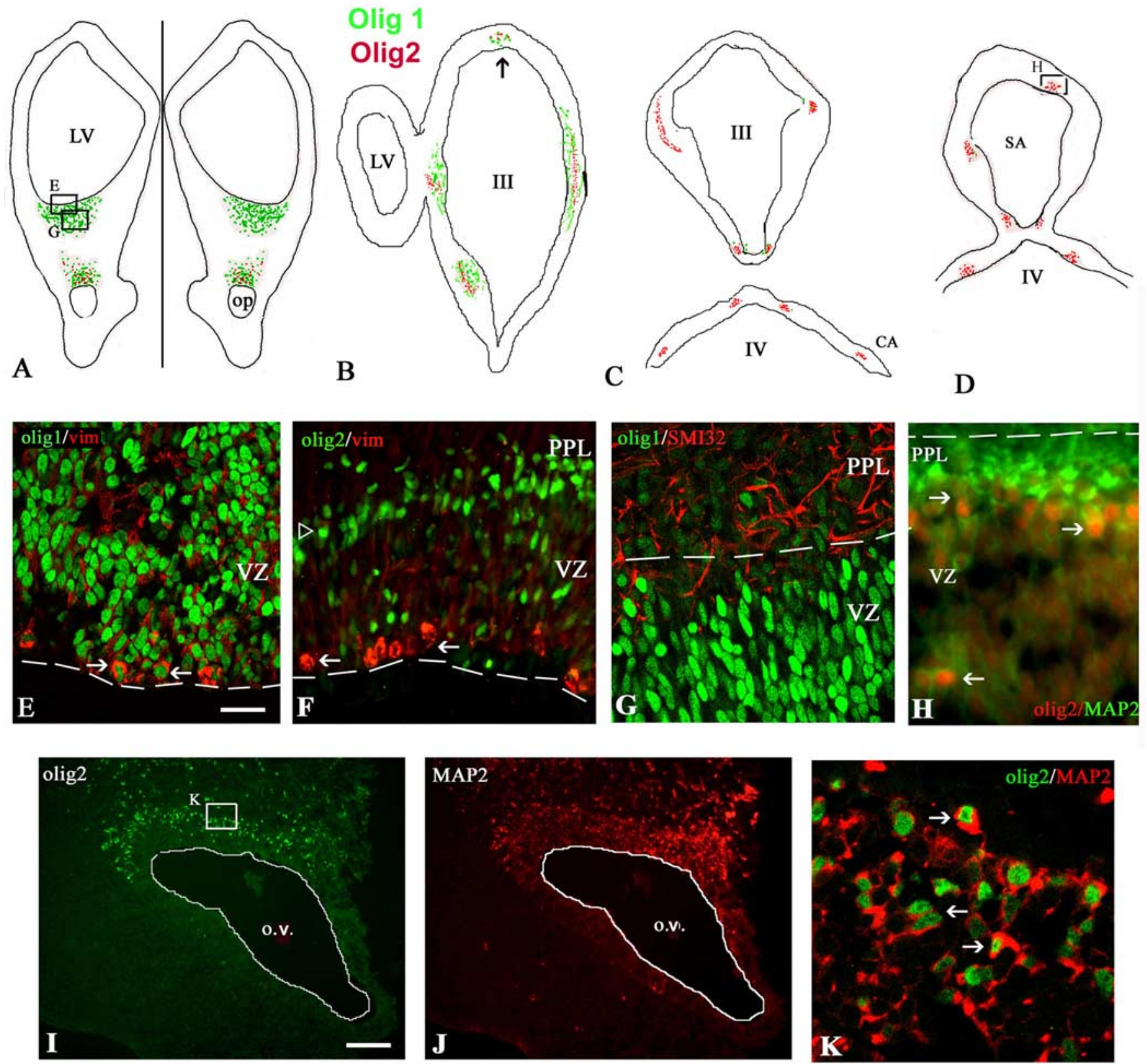

Figure 1. Olig1 and 0lig2 are present in the same regions but in different cell types in the $5 \mathrm{GW}$ human embryos. $A-D$, Drawings of a series of frontal sections through the $5 \mathrm{GW}$ embryonic brain showing 0 lig 1 (green dots) and Olig2 (red dots) expression. $\boldsymbol{A}$, In the rostral telencephalon, the immunoreaction is localized ventrally, in the VZ, and around the olfactory vesicle (0.v.). $\boldsymbol{B}$, At the level of the diencephalon, both 0 lig1 and 0 lig2 are expressed in the lateral wall and dorsally at the midline (arrow). An asymmetric cut displays the left cerebral vesicle, which is without immunoreaction. At more caudal levels through the diencephalon-mesencephalon ( () , the cerebellar anlage (CA), and the mesencephalon-rhombencephalon (D), only 0lig2 is expressed. The boxed areas are shown on corresponding pictures. $\boldsymbol{E}$, Double immunofluorescence of the ventral telencephalic VZ shows Olig ${ }^{+}$nuclei (green) in dividing vimentin ${ }^{+}$(red) cells on the VZ surface (arrows). $\boldsymbol{F}, 0$ lig2 ${ }^{+}$nuclei (green) are positioned distally (arrowhead), bordering the PPL, and are not found in vimentin ${ }^{+}$cells (red) on the VZ surface (arrows). G, No overlap is seen between 0 lig1 (green) expressed in VZ cells and neurofilament SMI-32 (red) expressed in neuronal processes in the PPL. $\mathrm{H}, 0$ lig2 ${ }^{+}$nuclei (red) in selected MAP2 ${ }^{+}$cells (green) at the border of the VZ and the PPL (arrows). Double labeling with 0 lig2 $(\boldsymbol{I})$ and MAP2 $(\boldsymbol{J})$ around the olfactory vesicle shows the overlapping distribution of these markers in cells migrating toward the basal telencephalon. $\boldsymbol{K}$, Higher-magnification confocal image from the boxed region in I shows that most of the cells are colabeled (arrows). LV, Lateral ventricle; III, third ventricle; SA, Sylvius aqueduct. Scale bars: $\boldsymbol{E}-\boldsymbol{H}, 20 \mu \mathrm{m} ; \boldsymbol{I}, \boldsymbol{J}, 100 \mu \mathrm{m} ; \boldsymbol{K}, 15 \mu \mathrm{m}$.

lated neurofilament SMI-32 (1:1000; Sternberger Monoclonal), neuronal-specific nuclear protein (NeuN) (1:100; Chemicon), GABA (1:1000; Sigma), and Reelin [1:500; gift from Dr. M. Ogawa, Kochi Medical School, Kochi, Japan (Ogawa et al., 1995)]. Radial glia were labeled with vimentin antibody (mouse, 1:100; Sigma), neural progenitor cells were labeled with nestin (mouse, 1:200; Neuromics, Northfield, MN), and astrocytes were labeled with glial fibrillary acidic protein (GFAP) (mouse, 1:25; Dako Cytomation, Carpinteria, CA).

Controls were done by omitting the primary antibody, which resulted in a lack of immunofluorescence. In the case of Olig1 and Olig2, the specificity of antibodies was tested by Western blot analysis of a wholebrain homogenate; single bands of the appropriate molecular weight (32 and $30 \mathrm{kDa}$ ) were obtained with Olig2 and Olig1, respectively (supplemental Fig. 1, available at www.jneurosci.org as supplemental material). To support the specificity of the antibodies, in situ hybridization sections with Olig1 and Olig2 RNA probes from the same brain regions were compared with immunofluorescence results.

Quantification of dissociated cell culture. Immunolabeled cells were 


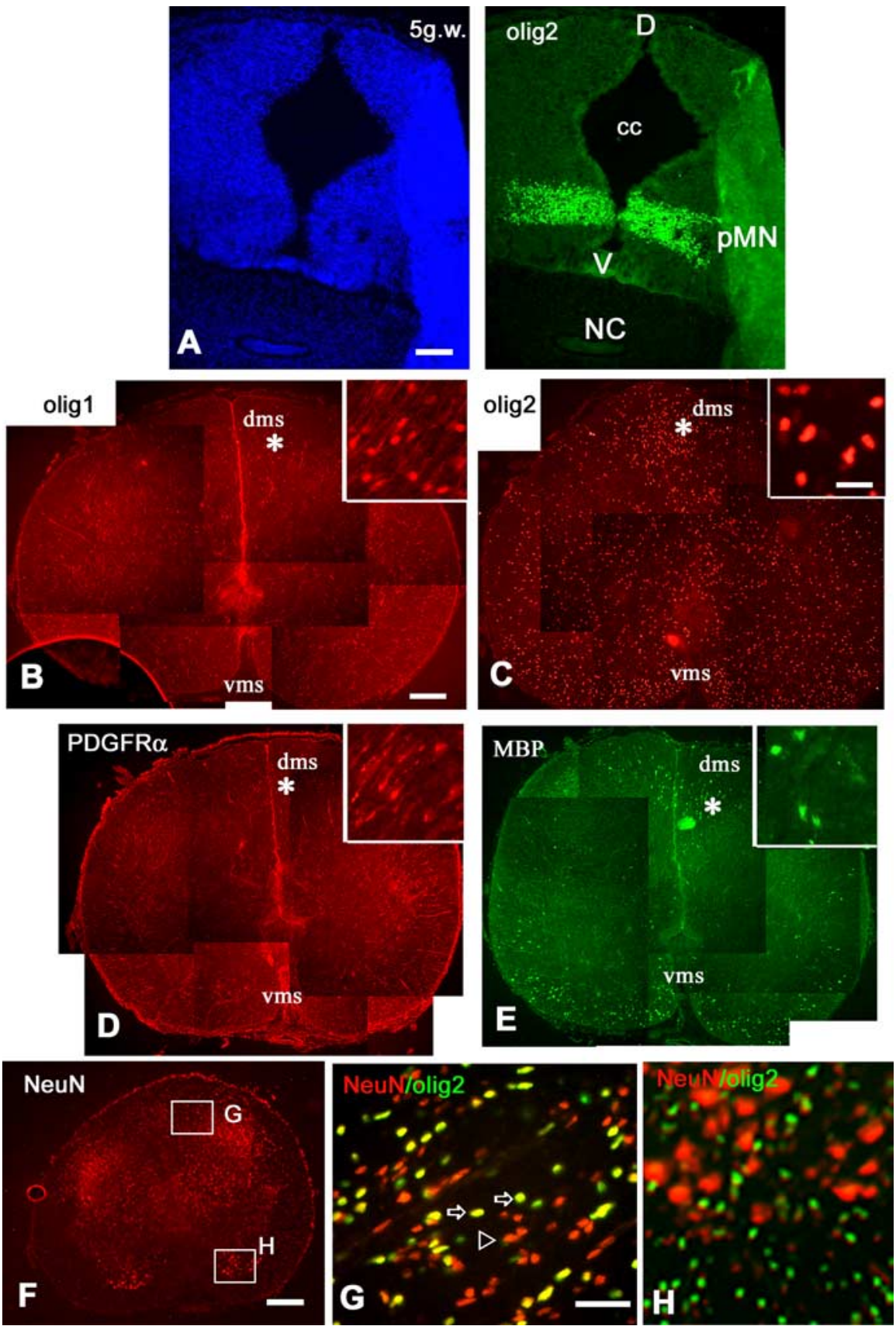

Figure 2. Expression of 0lig1 and Olig2 and cell-specific markers in the spinal cord. $A$, Left, Bisbenzimide nuclear counterstaining of the $5 \mathrm{GW}$ spinal cord. Right, Olig2 expression confined to the horizontal band, $\sim 50 \mu \mathrm{m}$ wide, at the pMN level of the ventral spinal cord. $\boldsymbol{B}, \boldsymbol{C}$, At $15 \mathrm{GW}$, the cross section through the thoracic level of the spinal cord demonstrates Olig1 (B) and 0lig2 ( $\boldsymbol{C}$ ) immunoreactivity distributed throughout the entire section. Asterisks in the dorsal funiculus mark the area of the highermagnification images shown in the corresponding insets. PDGFR- $\alpha^{+}$cells $(\boldsymbol{D})$ and MBP ${ }^{+}$cells $(\boldsymbol{E})$ aggregate in the developing white matter in the dorsal and ventral funiculus. $\mathbf{F}-\boldsymbol{H}, \mathrm{NeuN}^{+}$cells in the gray matter of the spinal cord. Small rectangles show the sites for the corresponding pictures. $\mathbf{G}$, In the dorsal funiculus, double labeling with Olig2 (green) and NeuN (red) results in numerous double-labeled cells (yellow; arrows) but also single-labeled NeuN ${ }^{+}$cells (open arrowhead). $\boldsymbol{H}$, In the ventral horn, MNs labeled with NeuN (red) do not express Olig2 (green). g.w., Gestational weeks; D, dorsal; V, ventral; cc, central canal; NC, notochord; dms, dorsal median septum; vms, ventral median sulcus. Scale bars: $\boldsymbol{A}-\boldsymbol{E}, 50 \mu \mathrm{m} ; \boldsymbol{B}-\boldsymbol{E}$, insets, $15 \mu \mathrm{m} ; \boldsymbol{F}, 100 \mu \mathrm{m} ; \boldsymbol{G}$, H, $25 \mu \mathrm{m}$.

counted and expressed as a percentage of the total number of cells viewed with nuclear stain (bisbenzimide). Ten adjacent optical fields (surface of one field $=264.33 \mu \mathrm{m}^{2}$ ) were examined at $20 \times$ magnification in each culture. Means \pm SDs were calculated and compared between two examined regions: the cortical and GE VZ-SVZ. Values of $p<0.05$ were considered significant in the Student's $t$ test.

\section{Results}

Distribution of Olig1 and Olig2 in the human embryonic brain and spinal cord To better understand the role of Olig transcription factors in the early specification of cells in the human embryonic CNS, we studied their distribution in 5-5.5 GW embryos [Carnegie stages 16-17 (O’Rahilly et al., 1987)]. Olig1 and Olig2 were expressed in the ventral part of the forebrain and hindbrain, including the cerebellar anlage (Fig. 1A-D). Olig1 was prevalent in the telencephalon, whereas both genes were distributed around the olfactory vesicle and in the ventral and lateral VZ of the diencephalon (Fig. $1 A, B, I$ ). The exception to this ventrolateral distribution was in a distinct dorsal region around the midline of the diencephalon, where a small number of nuclei expressed Olig1 and Olig2 (Fig. $1 B$, arrow).

The distribution of the two transcription factors within the VZ showed noticeable differences. Olig1 was expressed throughout the entire width of the VZ, whereas Olig2 was mostly expressed in the distal part, at the border of the VZ with the primordial plexiform layer (PPL) (Fig. $1 E, F)$. Rarely were Olig2 cells seen in the middle of the VZ, and none were located on the ventricular surface. This distribution was observed in both the telencephalon and the diencephalon (Fig. $1 E-H$ ). Consistent with this, RG cells on the VZ surface expressed Olig1 (Fig. 1E) but not Olig2, which was absent at this location (Fig. $1 F$ ). Instead, Olig2 was shown at the upper border of the VZ with the PPL, in the nuclei of MAP2 ${ }^{+}$neurons (Fig. $1 H$ ). Similarly, a diverse cellular colocalization of these two markers was found in the olfactory vesicle, where single cells displayed Olig2 in the nucleus and MAP2 in the cytoplasm (Fig. $1 \mathrm{~K}$ ). In contrast, Olig1 was not colocalized in telencephalic neurons, as seen with double labeling with phosphorylated neurofilament SMI-32, another neuronal marker (Fig. $1 G$ ). During the embryonic period, markers of OL lineage were not expressed in the human CNS and could not be tested for their colocalization with Olig transcription factors.

In the embryonic spinal cord (5 GW), Olig2 was expressed in a well delineated band that spanned the central canal to the lateral surface of the ventral spinal cord (Fig. 2A). In contrast, Olig1 was not expressed in the spinal cord at this embryonic age.

At $15 \mathrm{GW}$, the next developmental age available for our study, both Olig1 and Olig2 were distributed uniformly throughout the gray and white matter of the spinal cord (Fig. $2 B, C$ ). On consec- 

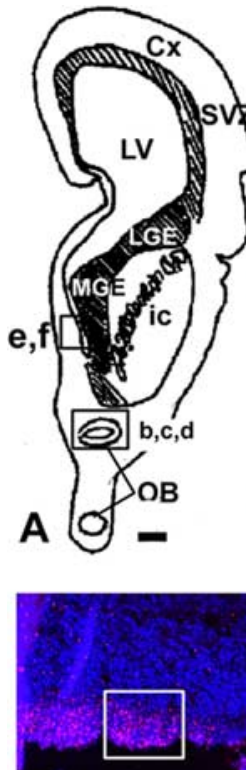

OV
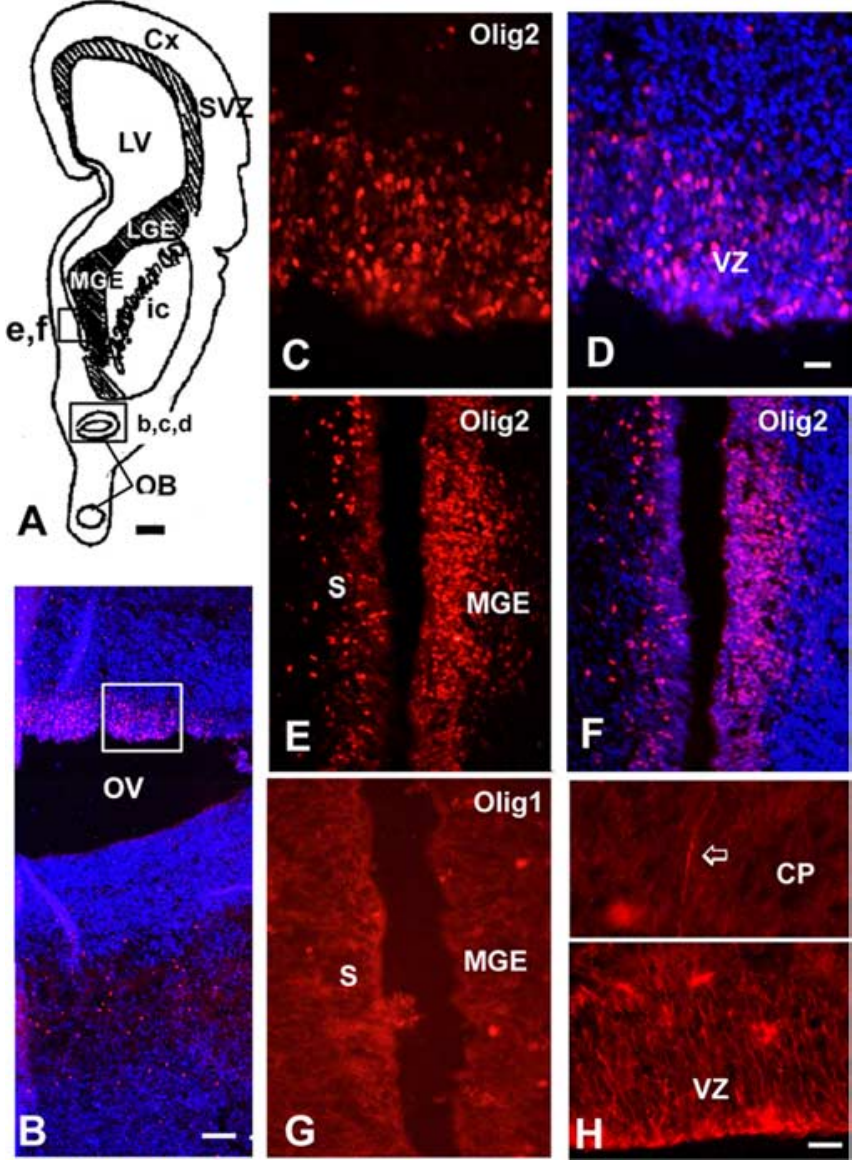

Olig2
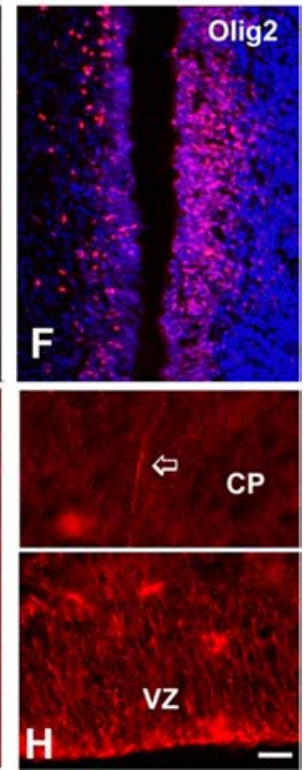

Figure 3. Olig1 and 0lig2 in the fetal telencephalon at $15 \mathrm{GW}$. A, Drawing of a frontal section through the right hemisphere at the level of the olfactory bulb (OB). Boxed areas indicate the areas where the corresponding photographs were taken. $\boldsymbol{B}$, Olig2 is expressed in the VZ of the dorsal region of the olfactory vesicle (OV) and in scattered nuclei in the ventral region. $\boldsymbol{C}, \boldsymbol{D}$, Higher magnification of boxed area in $\boldsymbol{B}$. $\boldsymbol{D}$, The same section counterstained with bisbenzimide (blue). $\boldsymbol{E}, \boldsymbol{F}$, The high density of Olig2 ${ }^{+}$nuclei is present in the $\mathrm{VZ}$ of the MGE, whereas a smaller number of dispersed 0 lig ${ }^{+}$nuclei are found in the septal area (S). $\boldsymbol{G}, \boldsymbol{H}$, In the consecutive section, 0 lig1 is expressed in radial fibers, both in the MGE region (G) and in the cortical VZ and cortical plate $(C P)(H)$. LV, Lateral ventricle; $C x$, cerebral cortex; LGE, lateral GE; ic, internal capsule; $\mathrm{e}, \mathrm{f}, \mathrm{b}, \mathrm{C}, \mathrm{d}$ (in $\boldsymbol{A}$ ) correspond to photographs. Scale bars: $\boldsymbol{A}, 1 \mathrm{~mm} ; \boldsymbol{B}, 100 \mu \mathrm{m} ; \boldsymbol{C}, \boldsymbol{D}, 20$ $\mu \mathrm{m} ; \boldsymbol{E}-\boldsymbol{H}, 20 \mu \mathrm{m}$

utive sections of the spinal cord, Olig1 and PDGFR- $\alpha$ showed overlapping distributions through both gray and white matter (Fig. 2B,D); however, the expression of Olig2 was more pronounced than Olig1, and a slight accumulation of Olig2 ${ }^{+}$nuclei was seen in the developing white matter of the dorsal and ventral funiculi (Fig. 2C). These locations also harbored numerous $\mathrm{MBP}^{+}$OLs (Fig. 2 E). Numerous postmitotic neurons $\left(\mathrm{NeuN}^{+}\right)$ in the gray matter were colabeled with Olig2. These doublelabeled NeuN-Olig2 neurons were distributed through the dorsal funiculus and belonged to interneurons, as determined by their cell morphology, size, and localization in the gray matter (Fig. $2 \mathrm{~F}$, $G)$. Motor neurons, localized in the developing ventral horns, were large $\mathrm{NeuN}^{+}$cells not colabeled with Olig2 (Fig. $2 \mathrm{H}$ ). At this age, Olig1 was not expressed in $\mathrm{NeuN}^{+}$spinal cord neurons, as determined by double labeling (data not shown).

In the telencephalon at $15 \mathrm{GW}$, numerous Olig ${ }^{+}$nuclei were demonstrated in a well delineated region of the olfactory vesicle (Fig. 3B). Olig2 ${ }^{+}$nuclei were dense in the upper VZ, whereas they were dispersed away from the vesicle on its ventral side (Fig. $3 B, D)$. In the rostral telencephalon, Olig2 had a well outlined expression pattern through the VZ-SVZ of the MGE and the lateral GE (Fig. $3 E, F$ ) but was entirely absent in the cortical VZ at this developmental stage (data not shown). Olig1, on the other hand, was expressed in radial fibers that span the VZ through the upper cortical regions but was not localized in the cell nuclei (Fig. $3 G, H)$.

We concluded that the distribution of Olig1 and Olig2 had complementary patterns of expression in the human embryonic (5 GW) forebrain and spinal cord. At $5 \mathrm{GW}$, Olig2 showed a caudorostral gradient, from strong expression in the spinal cord to complete absence in the telencephalon. Olig1 at the same gestational age was strongly expressed in the telencephalon, as opposed to the total lack of expression in the spinal cord. Moreover, at $5 \mathrm{GW}$, Olig1 was expressed by RG cells on the VZ surface, whereas Olig2 was mostly expressed by newborn neurons. With the progression of development, Olig2 became expressed in the ventral telencephalon, invading more rostral and dorsal regions.

\section{Distribution of Olig1 and Olig2 genes in the forebrain at midgestation}

The expression of Olig1 and Olig2 was studied further at midgestation (17-24 GW), a developmental period that is characterized by proliferation of both neuronal and OL progenitors in the SVZ, followed by their migration and differentiation.

At midgestation, both olig transcription factors were widespread throughout all parts of the forebrain (Fig. 4A,B); however, the strongest immunosignal was detected in the proliferative $\mathrm{VZ}$ and SVZ, on both the cortical and GE sides (Fig. 4B-D). The white matter also contained numerous Olig $1^{+}$and Olig2 ${ }^{+}$ nuclei (Fig. $4 B$ ). In the GE, Olig $1^{+}$nuclei were concentrated in the SVZ, whereas Olig2 ${ }^{+}$nuclei were mainly positioned close to the VZ surface (Fig. 4C). In the cortical VZ-SVZ, Olig1 was expressed in the cytoplasm and rarely in nuclei of cells running in the narrow "stream" of cells in the lateral SVZ (Figs. 4D, 5A), in accord with our previous results (Rakic and Zecevic, 2003). On the other hand, Olig2 ${ }^{+}$nuclei were dispersed uniformly throughout the VZ-SVZ and not confined to the stream (Fig. $4 D)$. In the cortical plate, the number of cells expressing Olig1 and Olig2 and their mRNAs was lower than in either the cortical SVZ or the emerging white matter (Fig. $4 E, F$ ).

A series of double-immunolabeling experiments were performed to characterize cells that expressed olig transcription factors. Olig1, in the narrow stream of cells in the SVZ and emerging white matter, was coexpressed with the early OL progenitor markers PDGFR- $\alpha$ and NG2 (Fig. $5 A, B$ ) but not with MBP, a marker of more mature OLs (Fig. $5 C$ ), or neuronal markers (MAP2 and NeuN; data not shown).

A fraction of vimentin ${ }^{+}$fibers in the white matter were colabeled with Olig1, similar to the observation at $15 \mathrm{GW}$ (Fig. 5F). Occasionally, a bipolar cell, with two processes extending in opposite directions resembling RG, was labeled with Olig1 (Fig. 5F, inset). Olig2, on the other hand, was expressed ubiquitously in the emerging white matter in the nuclei of late OL progenitor cells $\left(\mathrm{O}^{+}\right)$(Fig. 5I) and mature and premyelinating $\mathrm{OLs}\left(\mathrm{O}^{+}\right.$and $\mathrm{MBP}^{+}$) (Fig. 5G-I). Olig2 was also expressed in a small subset of $\mathrm{NG}^{+}{ }^{+}$cells located in the subplate layer (Fig. $5 \mathrm{~K}$ ) and in the olfactory bulb. Astrocytes, labeled with GFAP, did not express either Olig1 (Fig. 5D) or Olig2 (Fig. 5E).

At midgestation, Olig2 was found in a subset of $\mathrm{MAP}{ }^{+}$neurons in the cortical VZ (Fig. $5 L$ ), as well as in MAP2 ${ }^{+}$cells that look like they are migrating through the SVZ cell bands (Fig. 5M), but not in cortical GABAergic neurons (Fig. 5O). In layer I, a subpopulation of small cells expressed Olig2 and could be colabeled with NG2, which 


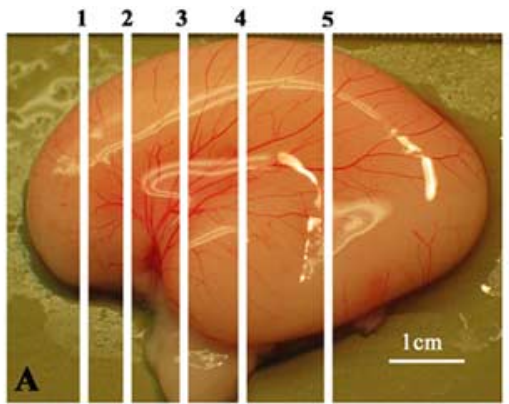

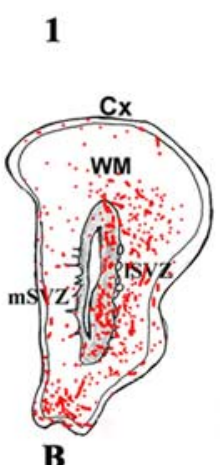

2
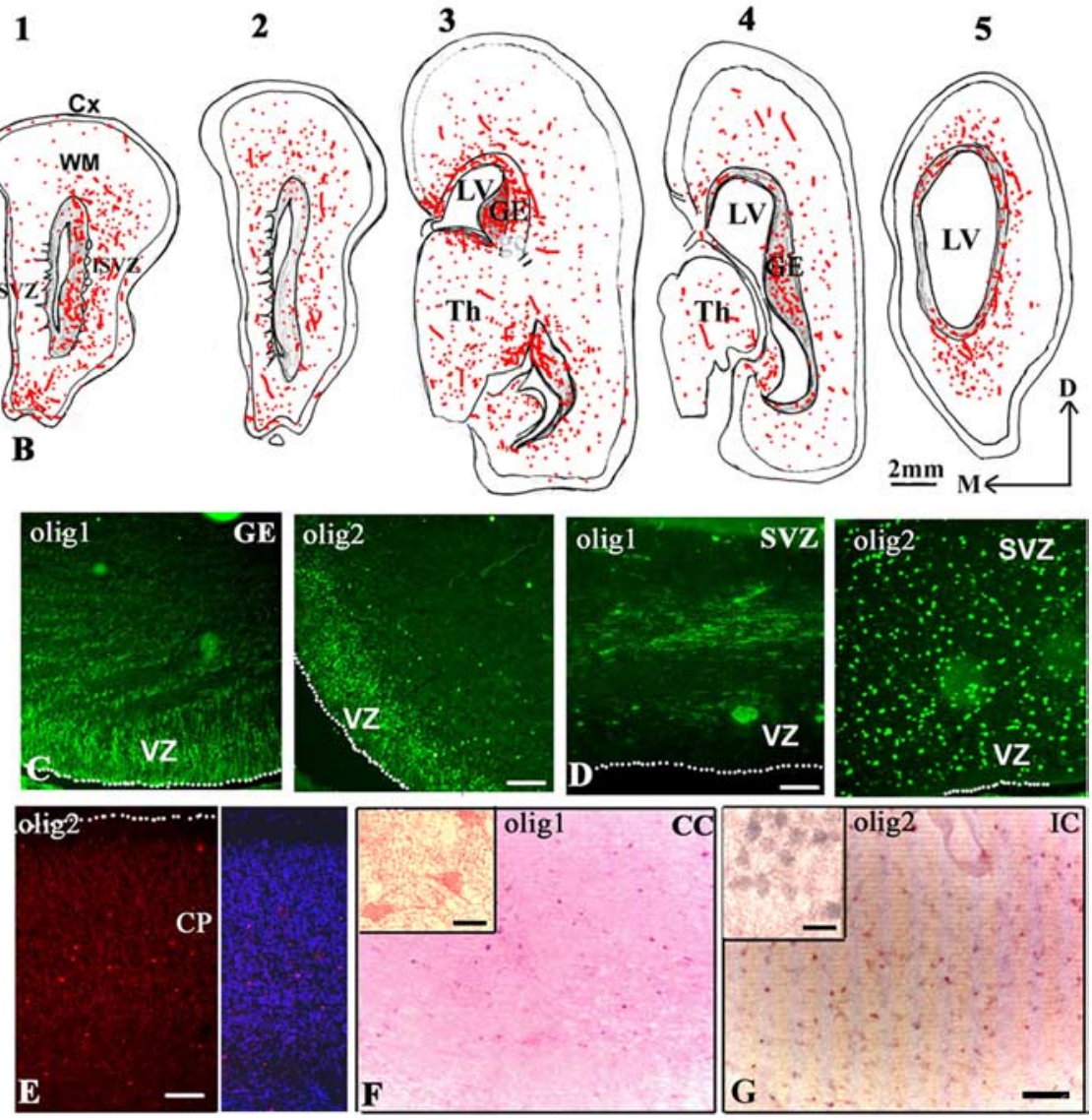

Figure 4. Olig1 and Olig2 in the human fetal brain at midgestation. $\boldsymbol{A}$, Typical hemisphere of the $19 \mathrm{GW}$ fetus with lines representing rostrocaudal levels where tissue blocks were dissected. $\boldsymbol{B}$, Drawings of frontal sections from rostral (1) to caudal (5) with relative distribution of Olig2 expression (red dots). Note the strong expression in the SVZs of the GE. $\boldsymbol{C}$, In the GE of a $22 \mathrm{GW}$ fetus, 0 lig $1^{+}$nuclei (left) are present in the VZ and SVZ; 0lig2 ${ }^{+}$nuclei (right) are located mostly at the VZ surface. D, In the cortical VZ-SVZ, Olig1 (left) is confined to a narrow stream of cells in the SVZ; 0lig2 (right) is distributed evenly throughout this region. $\boldsymbol{E}$, Expression of 0 lig2 in the cortical plate $(C P)$ is very weak; the right panel represents bisbenzimide staining of the same section. $\boldsymbol{F}, \mathbf{G}, 0$ lig1 $(\boldsymbol{F})$ and Olig2 $(\boldsymbol{G})$ mRNA in the white matter of the midgestational forebrain. Insets are high-power images. $M_{\text {, }}$ Medial; D, dorsal; LV, lateral ventricle; IC, internal capsule; cc, corpus calllosum; Th, thalamus; WM, white matter. Scale bars: $\mathbf{C}-\mathbf{G}$, $50 \mu \mathrm{m} ; \boldsymbol{F}, \mathbf{G}$, insets, $10 \mu \mathrm{m}$.

indicates that they belong to OL lineage; however, neither large Cajal-Retzius cells, labeled with Reelin (Fig. 5N) and SMI-32 (data not shown), nor postmitotic neurons in the cortical plate, revealed by NeuN antibody, expressed Olig2 (Fig. 5P). We concluded that, at midgestation, Olig2 was expressed mainly by OLs and a subpopulation of still migrating, immature neurons, whereas the expression of Olig1 was restricted to early OL progenitors and RG fibers.

\section{Subcellular distribution of Olig1 and Olig2}

In the $5 \mathrm{GW}$ embryonic brain, both Olig1 and Olig2 were localized exclusively in cell nuclei (Fig. $1 E-I$ ); however, in the fetal

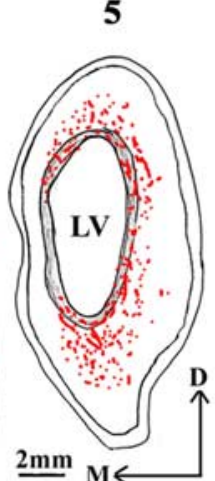

stages (15-24 GW), there was a substantial redistribution of Olig1 from the nucleus to the cytoplasm of the cell. Although in some regions of the white matter Olig1 still had nuclear localization, numerous immature progenitor cells in the SVZ expressed Olig1 only in the cytoplasm of the cell bodies and processes, but not in the nuclei (Fig. 5A). In contrast, Olig2 was always expressed in cell nuclei and not in the cytoplasm. These results, obtained with immunohistochemistry on brain sections, were confirmed by immunoblot analysis of fetal brains at midgestation (19 and 22 GW); in all brain regions tested, Olig1 was detected mainly in the cytoplasmic fraction (supernatant) and much less in the nuclear fraction (Fig. $6 A$ ), whereas Olig2 was present only in the nuclear fraction (Fig. 6B).

Quantification of cells expressing Olig2 in the cultured VZ-SVZ cells at midgestation

To quantify cells that express Olig2 in the fetal VZ-SVZ at midgestation and to test their proliferative capabilities, we established acutely dissociated cell cultures from the VZ-SVZ region of the fetal brain at midgestation (19-22 GW).

Four hours after plating, Olig2 ${ }^{+}$cells were significantly more frequent in cultures from the proliferative zones of the GE-VZ-SVZ than from cortical VZ-SVZ (Fig. 7A). BrdU incorporation showed that Olig ${ }^{+}$cells entered S phase and presumably were proliferating in cultures from both the GE and cortical VZ-SVZ. The average BrdU incorporation rate was two times higher for Olig2 ${ }^{+}$cells $(19.6 \pm$ $2.8 \%)$ than for the overall VZ-SVZ cell population $(10.9 \pm 0.6 \%)$ (Fig. $7 B$ ). The overall percentage of Olig $2^{+}-\mathrm{BrdU}^{+}$cells in the VZ-SVZ was $1.3 \pm 0.2 \%$.

To further characterize Olig2 ${ }^{+}$cells in the cortical VZ-SVZ in vitro, we double labeled acutely dissociated cells with Olig2 and GFAP for astrocytes, with PDGFR- $\alpha$ for early oligodendrocyte progenitor cells (OPCs), or with nestin for neural progenitor cells. The percentage of Olig2-nestin ${ }^{+}$ and Olig2-PDGFR- $\alpha^{+}$cells from all nestin or all PDGFR- $\alpha$ cells in the cortical VZ-SVZ was very high $(62 \pm 16 \%$ and $51 \pm 10 \%$, respectively) (Fig. $7 C, D$ ). There was no significant colabeling of Olig2 ${ }^{+}$cells with GFAP. Additionally, in accord with results obtained on tissue sections from the forebrain, $\mathrm{NeuN}^{+}$postmitotic neurons could not be colabeled with Olig2 in cell cultures from either the GE or the cortical VZ-SVZ (data not shown).

We concluded that, at midgestation, Olig2 labeled mitotic cells in the cell culture of the VZ-SVZ region. The proliferation rate of Olig ${ }^{+}$cells was higher than that of the overall cell population in the VZ-SVZ. In vitro double-labeling experiments demonstrated that Olig2 is being expressed in early OL progenitor cells or stem cells. 

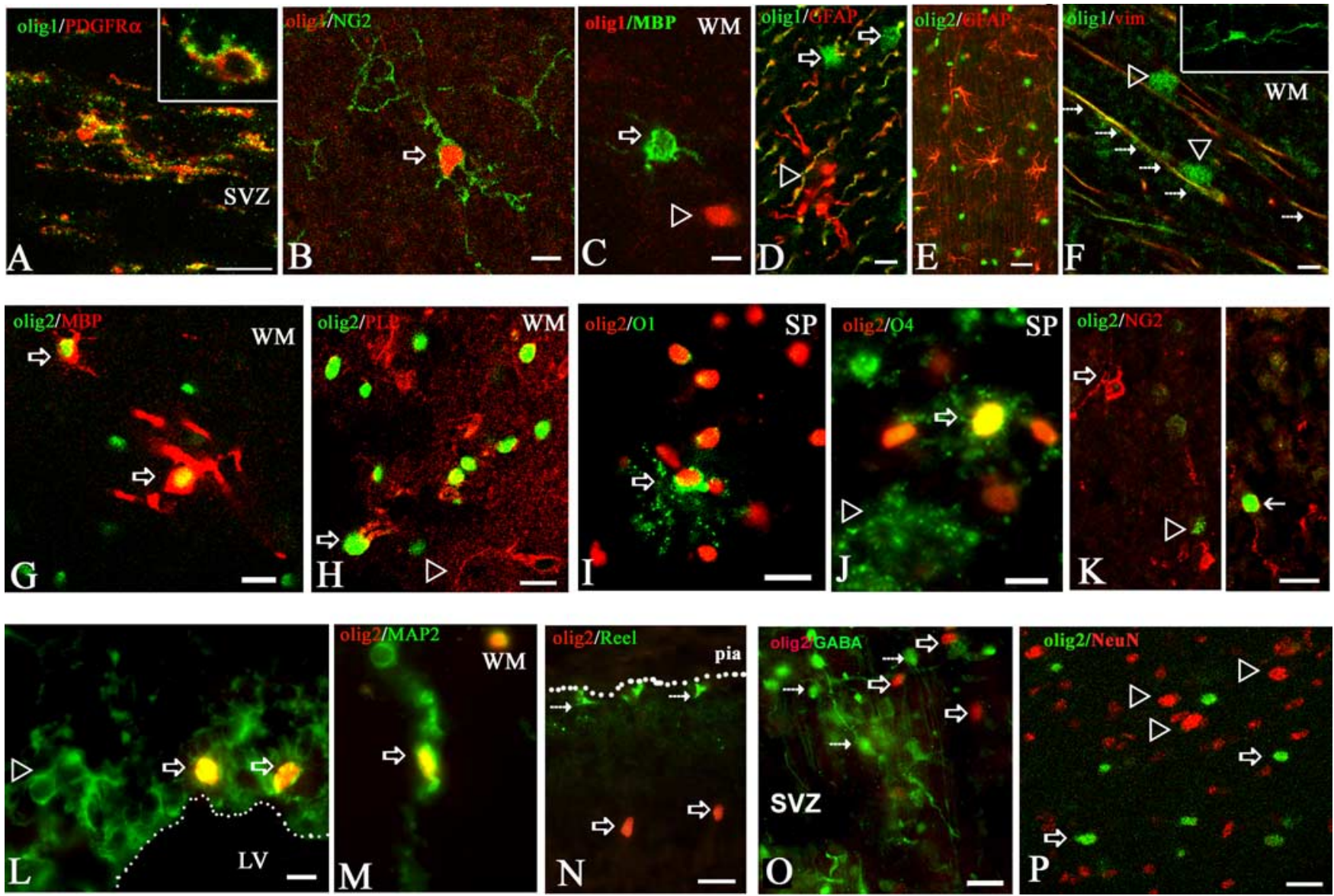

Figure 5. Cell-specific expression of Olig1 and 0lig2 at midgestation (17-24 GW). $\boldsymbol{A}-\boldsymbol{F}$, Olig1 is expressed in $0 \mathrm{~L}$ progenitors and RG but not in mature $0 \mathrm{Ls}$ or in astrocytes. $\boldsymbol{A}$, Double-labeling immunofluorescence revealed that the stream of cells in the SVZ coexpresses PDGFR- $\alpha$ (red) and Olig1 (green). The inset shows a single cell from the stream. $\boldsymbol{B}$, In the white matter, 0 lig1 (red) is expressed in the nucleus of the $\mathrm{NG}^{+}$(green) early $\mathrm{OPC}$ (arrow). $\mathbf{C}, \mathrm{MBP}^{+}$(green; arrow) $0 \mathrm{~L}$ in the diencephalic white matter does not express 0 lig1 (red; arrowhead). $\boldsymbol{D}, 0$ lig ${ }^{+}{ }^{\text {nuclei }(\mathrm{green} ;}$ arrows) among GFAP ${ }^{+}$astrocytes (red; arrowhead) and fibers in the white matter. $\boldsymbol{E}$, Olig2 ${ }^{+}$nuclei (green) are not present in $\mathrm{GFAP}^{+}$astrocytes (red) in the subplate layer. $\boldsymbol{F}$, Some vimentin ${ }^{+}$ fibers (red) in the white matter express Olig1 (green), which results in yellow colabeling (arrows). Note that 0lig ${ }^{+}$nuclei do not express vimentin (open arrows). The inset shows a threedimensional reconstruction of a single 0 lig 1 cell, which appears to have a bipolar migratory morphology with long processes. $\mathbf{G}-\boldsymbol{K}, 0$ lig 2 is found in late $0 \mathrm{~L}$ progenitors and premyelinating $0 \mathrm{Ls}$ and only occasionally in early $0 \mathrm{~L}$ progenitors. $\mathbf{G}, 0$ lig2 (green; yellow on overlaid image) is expressed in the nuclei of $\mathrm{MBP}^{+}$(red) $\mathbf{~ c e l l s . ~} \boldsymbol{H}, 0$ lig2 and PLP (red) in the white matter are colocalized in a subset of cells (arrow) but not in all (arrowhead). I, Confocal image of a single $01^{+}$premyelinating $0 \mathrm{~L}$ (green) in the subplate layer of the parietal cortex with nuclear expression of 0 lig2 (red; arrow). $J$, A subset of $04^{+} 0 \mathrm{~L}$ progenitors (arrow) expressed 0 lig2 (green; yellow on overlaid image), whereas others did not (arrowhead). $\boldsymbol{K}$, NG2 ${ }^{+}$early $0 \mathrm{~L}$ progenitors (red; arrow) in the white matter (left) with migratory morphology do not express 0 lig2 (green; open arrowhead); however, other NG2 ${ }^{+}$cells in the white matter do (right; arrow). $\boldsymbol{L}-\boldsymbol{P}, 0$ lig2 in neurons. MAP2 ${ }^{+}$(green; arrowhead) neuronal progenitors in the $\mathrm{VZ}(\boldsymbol{L})$ and neurons migrating through the emerging white matter $(\boldsymbol{M})$ express 0 lig2 (red; arrows). $\boldsymbol{N}, 0$ lig2 ${ }^{+}$nuclei (red; open arrows) in layer I of the $15 \mathrm{GW}$ cortex were not colocalized with Reelin ${ }^{+}$Cajal-Retzius cells (green; arrows). O, GABAergic cells (green; arrows) do not express Olig2 (red; open arrows) in the cortical SVZ. $\boldsymbol{P}, \mathrm{NeuN}^{+}{ }^{+}$nuclei (red; arrowheads) in the cortical plate of the $22 \mathrm{GW}$ fetus do not coexpress Olig2 (green; arrows). LV, Lateral ventricle; WM, white matter. Scale bars: $A-D, F-K, P, 10 \mu \mathrm{m} ; \boldsymbol{L}, \boldsymbol{M}, 5 \mu \mathrm{m} ; \boldsymbol{N}, \mathbf{0}, 20 \mu \mathrm{m} ; \boldsymbol{E}, 25 \mu \mathrm{m}$.

\section{Discussion}

In this study, the expression of Olig1 and Olig2 transcription factors is demonstrated for the first time in the human developing CNS. Apart from many similarities, there are notable differences between the rodent and human developing CNS, both in timing and in the cell types that express these factors. In particular, Olig1 and Olig2 are expressed not only by cells of OL lineage, but also by RG and neurons, suggesting a wider role for these transcription factors in human CNS development.

\section{Olig transcription factors are expressed from embryonic stages in the human CNS}

The expression of Olig1 and Olig2 in well delineated areas of the embryonic CNS precedes the expression of the early OL progenitor markers PDGFR- $\alpha$ and NG2, consistent with results in the rodent spinal cord (Zhou et al., 2000; Lu et al., 2002; Takebayashi et al., 2002; Zhou and Anderson, 2002; Liu and Rao, 2004) and forebrain (Spassky et al., 1998; Tekki-Kessaris et al., 2001). It is interesting that at this early stage of development, in addition to mostly ventrolateral distribution, both factors are expressed in a well defined area of the dorsal diencephalon at the midline. This localization corresponds with the expression of $W N T 2 b$ proteins, which are believed to have a role in dorsoventral and left-right axes formation in the human embryonic brain (Abu-Khalil et al., 2004). Thus, dorsal expression of olig genes may have a function in axis formation. In addition, it may play a role in dorsal oligodendrogenesis, which was described to be Shh and Nkx6.1 independent in rodents (Cai et al., 2005; Fogarty et al., 2005; Miller, 2005; Vallstedt et al., 2005).

\section{Role of Olig1 and Olig2 transcription factors in OL specification}

The expression of Olig2 in the human embryonic spinal cord, in the same ventral regions shown in rodents to generate OLs under the control of Shh and Nkx6.1 (Richardson et al., 1997, 2000; Orentas et al., 1999; Lu et al., 2002; Miller, 2002; Rowitch et al., 

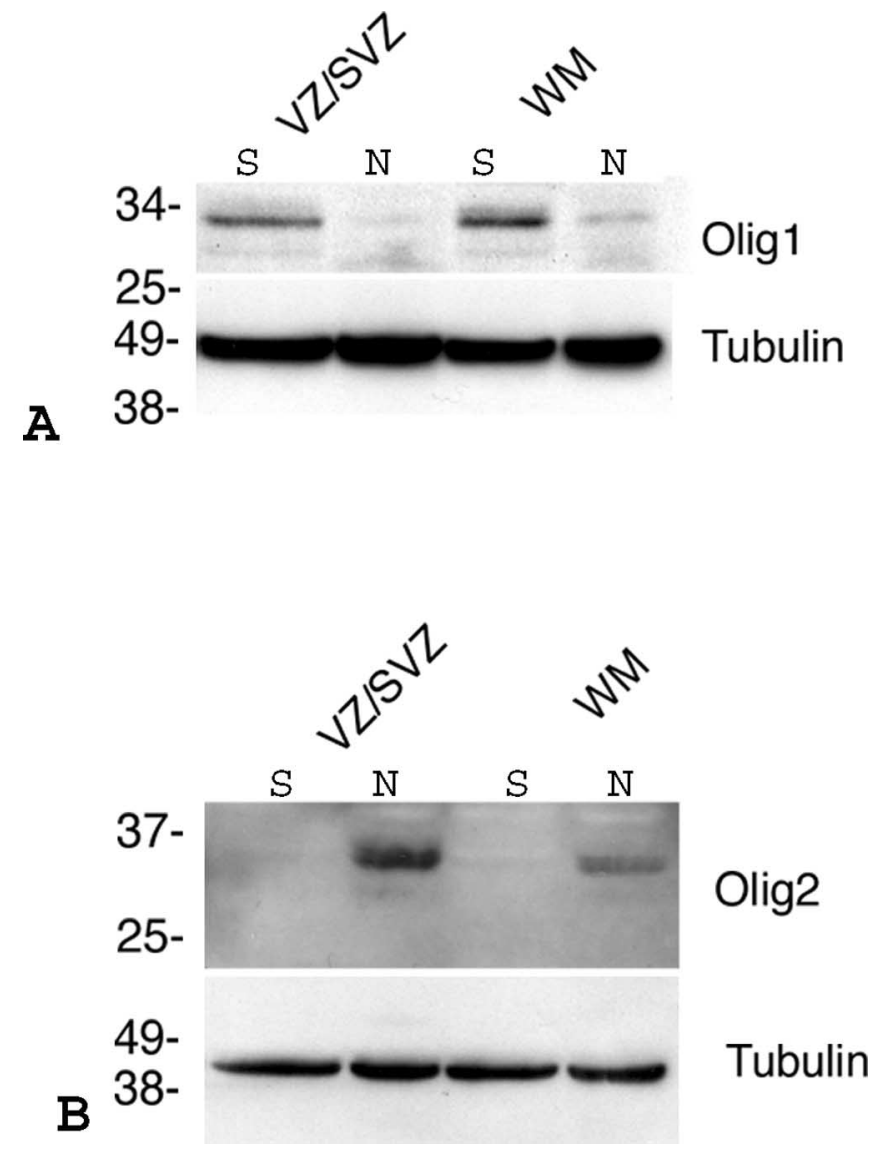

Olig2

Tubulin

Figure 6. Western blots of human fetal brain at 19 and $22 \mathrm{GW}$. 0 lig2 is present only in the nuclear fraction, whereas 0 lig1 is mainly cytoplasmic. Brain tissue was dissected into the cortical plate (CP), VZ-SVZ, and white matter. Tissue was lysed and subfractionated into nuclear and postnuclear (supernatant) fractions, which were further analyzed by immunoblot for 0lig1, Olig2, and tubulin (loading control). Olig1 $(\boldsymbol{A})$ is mainly cytoplasmic in all studied regions, whereas 0lig2 $(\boldsymbol{B})$ is present mainly in the nuclear fraction of the VZ-SVZ and white matter. Protein loading was $60 \mu$ g per lane; $n=2$ cases. N, Nuclear fraction; $S$, supernatant; WM, white matter.

2002; Takebayashi et al., 2002; Rowitch, 2004), suggests a role for Olig2 in the initial regulation of ventral oligodendrogenesis in the human spinal cord.

We show that the distribution of Olig1 and Olig2 proteins during fetal development (15-24 GW) continues to correlate well with the distribution of OL lineage cells reported for the fetal spinal cord and the forebrain (Back et al. 2001; Jakovcevski and Zecevic, 2005). It is characteristic that both Olig 1 and Olig2 are present in the ventral telencephalon through early fetal stages (5-15 GW), but between 15 and 20 GW, Olig2 expression spreads into the proliferative zones of the dorsal telencephalon. Olig2 is expressed at various stages of OL development during midgestation, from early OL progenitors $\left(\mathrm{NG}^{+}\right)$to more mature progenitors $\left(\mathrm{O}^{+}{ }^{+}\right)$and premyelinating OLs $\left(\mathrm{Ol}^{+}, \mathrm{PLP}^{+}\right.$, and $\left.\mathrm{MBP}^{+}\right)$. Olig1, on the other hand, is observed only in early OL progenitors (PDGFR- $\alpha^{+}$and $\mathrm{NG}^{+}$) or in the RG cells. These findings differ from reports in rodents and adult human brains, in which Olig1 is confined mainly to mature OLs (Arnett et al., 2004).

During human fetal development, we show a shift of Olig1 expression from a strictly nuclear to both nuclear and cytoplasmic localization at midgestation, the age that we described previously to be at the onset of myelination in the forebrain (Jakovcevski and Zecevic, 2005); in contrast, Olig2 has only nuclear

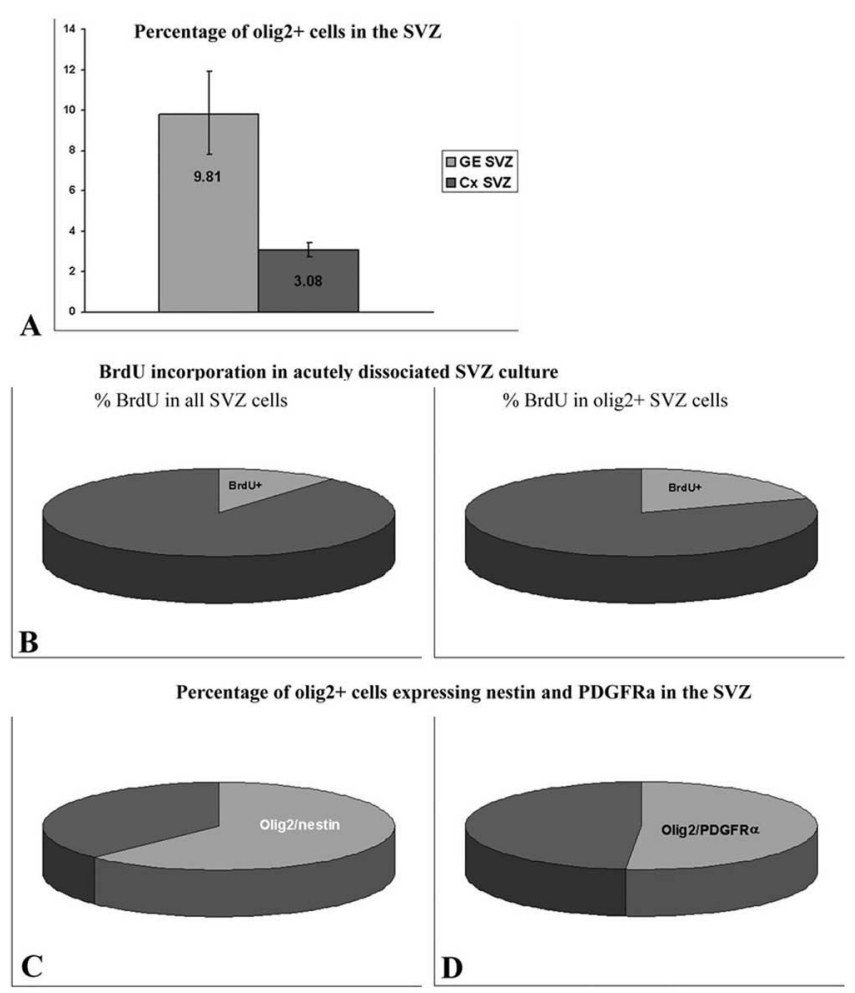

Figure 7. Olig2 in acutely dissociated VZ-SVZ cultures from midgestational (19-22 GW) fetal brains. $\boldsymbol{A}$, The difference in the percentage of 0 lig2 ${ }^{+}$cells in cultures from the GE VZ-SVZ (mean $\pm S D ; 9.81 \pm 2 \%$ ) versus cortical (Cx) VZ-SVZ (3.1 \pm 0.35$)$ is statistically significant $(p<0.005$; Student's $t$ test; $n=4) . B$, BrdU incorporation in VZ-SVZ cultures from the fetal human brain. Left, The overall percentage of $\mathrm{BrdU}^{+}$cells $(10.98 \pm 0.6 \%)$. Right, The percentage of BrdU ${ }^{+}$-0lig2 ${ }^{+}$cells $(19.6 \pm 3.07 \% ; p<0.01$; Student's $t$ test; $n=4)$. C, Percentage of 0 lig2 ${ }^{+}{ }^{+}$nestin ${ }^{+}$cells from all nestin ${ }^{+}$cells in the cortical cultures $(62.4 \pm 16.2 \% ; n=3)$. $D$, Percentage of 0lig ${ }^{+}-$PDGFR- $\alpha^{+}$cells from all PDGFR- $\alpha^{+}$cells in the cortical cultures $(51.4 \pm 5.7 \% ; n=3)$. The overall number is $>100 \%$, which supports the existence of a nestin ${ }^{+}$-PDGFR- $\alpha^{+}$cell population (Rakic and Zecevic, 2003).

localization. This subcellular localization of Olig1 may be related to OL differentiation and primary myelination, similar to what has been described during remyelination in animal models and multiple sclerosis lesions (Arnett et al., 2004). These authors speculate that nuclear localization of Olig1 prevents further differentiation of progenitors into mature OLs, which may be the main reason for failed remyelination attempts in multiple sclerosis (Arnett et al., 2004).

\section{Different progenitor cell classes express Olig transcription factors}

The localization of Olig1 and Olig2 indicates that these transcription factors specify different progenitor cell groups. In human fetal brain, Olig1, unlike Olig2, is found in RG cells, which are progenitors of cortical neurons. In contrast, studies in rodents report that Olig2 is expressed in RG from the MGE (Kriegstein and Gotz, 2003; Malatesta et al., 2003), or in RG and astrocytes in the cortical SVZ of neonatal rodents (Marshall et al., 2005). Others report that both Olig1 and Olig2 are present in the RG, prompting the concept of tripotent progenitors (Rao et al., 1998; Liu and Rao, 2004). Previous publications have also suggested that RG may be precursors of OLs (Choi and Kim, 1985; Choi, 1986), and this was confirmed in the rodent spinal cord (Fogarty et al., 2005). A common OL-astrocyte progenitor cell, named glia-restricted progenitor, isolated from the rodent spinal cord, 
gives rise to astrocytes and OLs in vitro (Rao et al., 1998; Gregori et al., 2002). Moreover, cell-fate mapping in the mouse brain shows that most cortical projection neurons, OLs, and astrocytes, but not interneurons, originate from the same Emxl transcription factor-expressing cells (Gorski et al., 2002).

Our double-labeling immunofluorescence studies suggest connections between the neuronal and OL lineages through shared Olig2 expression. Olig1 through its expression in both OL progenitors and RG, which later transform into astrocytes (Malatesta et al., 2000; Noctor et al., 2001, 2004), suggests a connection among OLs, astrocytes, and neuronal lineage, but we cannot identify a candidate for a common astrocyte-OL progenitor.

These differences may be explained by the different methods used, in vivo versus in vitro, as well as by species differences. For example, some factors may regulate Olig2 and GFAP expression in astroglial linage in opposite directions, so that young astrocytes express Olig2, but when astrocytes mature and start expressing GFAP, Olig2 is downregulated, as has been shown in rodents (Marshall et al., 2005). In humans, however, in whom GFAP is expressed in astroglial lineage from the early stages of development, Olig2 could not be found in astrocytes.

\section{Is Olig2 important for neurogenesis?}

Several lines of evidence indicate the existence of a common progenitor for cortical neurons and OLs in the forebrain, similar to previous findings in the spinal cord (Richardson et al., 2000; Rowitch et al., 2002). Both OLs and cortical interneurons originate in the GE (basal forebrain) and migrate to cerebral cortex, as shown in the mouse (He et al., 2001; Marshall and Goldman, 2002) and suggested in human fetal brain (Letinic et al., 2002; Rakic and Zecevic, 2003). In this study, we found Olig2 in several classes of neurons in the human fetal CNS, including olfactory neurons, postmitotic spinal cord interneurons, and migrating neurons in the cortical SVZ.

In the forebrain, Olig2 is expressed in early, possibly migrating $\mathrm{MAP}^{+}{ }^{+}$neurons in the SVZ, but not in more mature $\mathrm{NeuN}^{+}$ neurons in the cortical plate. In addition, we did not observe Olig2 in cortical GABAergic or calretinin ${ }^{+}$interneurons between 15 and $20 \mathrm{GW}$ in the time frame that we studied.

Because of their bipolar shape, Olig ${ }^{+}-\mathrm{MAP} 2{ }^{+}$cells around the olfactory vesicle at 5 and $15 \mathrm{GW}$ look like cells migrating toward the basal telencephalon, consistent with reports in rats that Olig2 is expressed by olfactory neurons (Takebayashi et al., 2000).

In the spinal cord, Olig2 is expressed in a subpopulation of $\mathrm{NeuN}^{+}$interneurons, but not in ventral MNs. This is in contrast to the results from Olig2 knock-out mice that found that Olig2 is important for the differentiation of MNs (Lu et al., 2002; Takebayashi et al., 2002). One cannot exclude downregulation of Olig2 expression in human MNs by $15 \mathrm{GW}$, the developmental age that we studied. These results suggest that the expression of olig genes in neurons is context dependent and influenced by cell type, maturation stage, and/or the CNS region.

\section{Conclusions}

Differences in Olig1 and Olig2 expression between the mouse and human CNS are notable in subcellular localization, cell types, stage-specific expression along OL lineage (OL progenitors vs mature OLs), and regional distribution in the CNS. At least some of these may be attributed to the complexity of the human brain and prolonged duration of development, during which specific stages of lineage progression become more apparent.

Although Olig1 and Olig2 are occasionally expressed by the same cells, this is not always the case. Their expression depends critically on the stage of development and the region of the CNS that is studied. Our immunofluorescence studies of the human fetal brain support the existence of a common neuronal-OL progenitor cell (Richardson et al., 2000; Rowitch et al., 2002).

It is likely that olig transcription factors specify OL lineage in the human forebrain and spinal cord in a way similar to that in animal models (Tekki-Kessaris et al., 2001), but the greater variety of cell types that express olig genes in the human CNS warrants further studies in the human brain related to their role, not only in OLs, but also in neuronal development.

\section{References}

Abu-Khalil A, Fu L, Grove EA, Zecevic N, Geschwind DH (2004) Wnt genes define distinct boundaries in the developing human brain: implications for human forebrain patterning. J Comp Neurol 474:276-288.

Altman J, Bayer SA (1984) The development of the rat spinal cord. Adv Anat Embryol Cell Biol 85:1-164.

Arnett HA, Fancy SP, Alberta JA, Zhao C, Plant SR, Kaing S, Raine CS, Rowitch DH, Franklin RJ, Stiles CD (2004) bHLH transcription factor Olig1 is required to repair demyelinated lesions in the CNS. Science 306:2111-2115.

Back SA, Luo NL, Borenstein NS, Levine JM, Volpe JJ, Kinney HC (2001) Late oligodendrocyte progenitors coincide with the developmental window of vulnerability for human perinatal white matter injury. J Neurosci 21:1302-1312.

Bansal R, Lakhina V, Remedios R, Tole S (2003) Expression of FGF receptors 1, 2, 3 in the embryonic and postnatal mouse brain compared with Pdgfralpha, Olig2 and Plp/dm20: implications for oligodendrocyte development. Dev Neurosci 25:83-95.

Bouvier C, Bartoli C, Aguirre-Cruz L, Virard I, Colin C, Fernandez C, Gouvernet J, Figarella-Branger D (2003) Shared oligodendrocyte lineage gene expression in gliomas and oligodendrocyte progenitor cells. J Neurosurg 99:344-350.

Cai J, Qi Y, Hu X, Tan M, Liu Z, Zhang J, Li Q, Sander M, Qiu M (2005) Generation of oligodendrocyte precursor cells from mouse dorsal spinal cord independent of Nkx6 regulation and Shh signaling. Neuron 45:41-53.

Choi BH (1986) Myelin-forming oligodendrocytes of developing mouse spinal cord: immunocytochemical and ultrastructural studies. J Neuropathol Exp Neurol 45:513-524.

Choi BH, Kim RC (1985) Expression of glial fibrillary acidic protein by immature oligodendroglia and its implications. J Neuroimmunol 8:215-235.

Fogarty M, Richardson WD, Kessaris N (2005) A subset of oligodendrocytes generated from radial glia in the dorsal spinal cord. Development 132:1951-1959.

Gorski JA, Talley T, Qiu M, Puelles L, Rubenstein JLR, Jones KR (2002) Cortical excitatory neurons and glia, but not GABAergic neurons, are produced in the Emx1-expressing lineage. J Neurosci 22:6309-6314.

Gregori N, Proschel C, Noble M, Mayer-Proschel M (2002) The tripotential glial-restricted precursor (GRP) cell and glial development in the spinal cord: generation of bipotential oligodendrocyte-type- 2 astrocyte progenitor cells and dorsal-ventral differences in GRP cell function. J Neurosci 22:248-256.

Hartfuss E, Galli R, Heins N, Götz M (2001) Characterization of CNS precursor subtypes and radial glia. Dev Biol 229:15-30.

He W, Ingraham C, Rising L, Goderie S, Temple S (2001) Multipotent stem cells from the mouse basal forebrain contribute GABAergic neurons and oligodendrocytes to the cerebral cortex during embryogenesis. J Neurosci 21:8854-8862.

Hoang-Xuan K, Aguirre-Cruz L, Mokhtari K, Marie Y, Sanson M (2002) Olig-1 and -2 gene expression and oligodendroglial tumours. Neuropathol Appl Neurobiol 28:89-94.

Jakovcevski I, Zecevic N (2005) Sequence of oligodendrocyte development in the human fetal telencephalon. Glia 49:480-491.

Jessell TM (2000) Neuronal specification in the spinal cord: inductive signals and transcriptional codes. Nat Rev Genet 1:20-29.

Kriegstein AR, Gotz M (2003) Radial glia diversity: a matter of cell fate. Glia 43:37-43. 
Letinic K, Zoncu R, Rakic P (2002) Origin of GABAergic neurons in the human neocortex. Nature 417:645-649.

Ligon KL, Alberta JA, Kho AT, Weiss J, Kwaan MR, Nutt CL, Louis DN, Stiles CD, Rowitch DH (2004) The oligodendroglial lineage marker OLIG2 is universally expressed in diffuse gliomas. J Neuropathol Exp Neurol 63:499-509.

Liu Y, Rao MS (2004) Olig genes are expressed in a heterogeneous population of precursor cells in the developing spinal cord. Glia 45:67-74.

Lu QR, Yuk D-I, Alberta JA, Zhu Z, Pawlitzky I, Chan J, McMahon AP, Stiles CD, Rowitch DH (2000) Sonic hedgehog-regulated oligodendrocyte lineage genes encoding $\mathrm{bHLH}$ proteins in the mammalian central nervous system. Neuron 25:317-329.

Lu QR, Park JK, Noll E, Chan JA, Alberta J, Yuk D, Alzamora MG, Louis DN, Stiles CD, Rowitch DH, Black PM (2001) Oligodendrocyte lineage genes (OLIG) as molecular markers for human glial brain tumors. Proc Natl Acad Sci USA 98:10851-10856.

Lu QR, Sun T, Zhu Z, Ma N, Garcia M, Stiles CD, Rowitch DH (2002) Common developmental requirement for olig function indicates a motor neuron/oligodendrocyte connection. Cell 109:75-86.

Malatesta P, Hartfuss E, Gotz M (2000) Isolation of radial glial cells by fluorescent-activated cell sorting reveals a neuronal lineage. Development 127:5253-5263.

Malatesta P, Hack MA, Hartfuss E, Kettenmann H, Klinkert W, Kirchhoff F, Gotz M (2003) Neuronal or glial progeny: regional differences in radial glia fate. Neuron 37:751-764.

Marshall CA, Goldman JE (2002) Subpallial Dlx2-expressing cells give rise to astrocytes and oligodendrocytes in the cerebral cortex and white matter. J Neurosci 22:9821-9830.

Marshall CA, Novitch B, Goldman JE (2005) Olig2 directs astrocyte and oligodendrocyte formation in postnatal subventricular zone cells. J Neurosci 25:7289-7298.

Miller RH (2002) Regulation of oligodendrocyte development in the vertebrate CNS. Prog Neurobiol 67:451-467.

Miller RH (2005) Dorsally derived oligodendrocytes come of age. Neuron 45:1-3.

Nery S, Wichterle H, Fishell G (2001) Sonic hedgehog contributes to oligodendrocyte specification in the mammalian forebrain. Development 128:527-540

Noctor SC, Flint AC, Weissman TA, Dammerman RS, Kriegstein AR (2001) Neurons derived from radial glial cells establish radial units in neocortex. Nature 409:714-720.

Noctor SC, Martinez-Cerdeno V, Ivic L, Kriegstein AR (2004) Cortical neurons arise in symmetric and asymmetric division zones and migrate through specific phases. Nat Neurosci 7:136-144.

Ogawa M, Miyata T, Nakajima K, Yagyu K, Seike M, Ikenaka K, Yamamoto H, Mikoshiba K (1995) The reeler gene-associated antigen on CajalRetzius neurons is a crucial molecule for laminar organization of cortical neurons. Neuron 14:899-912.

Olivier G, Pineau H (1962) Horizons de Streeter et age embrionnaire. Bull Ass Anat 47e:573-576.

O’Rahilly R, Muller F, Hutchins GM, Moore GW (1987) Computer ranking of the sequence of appearance of 73 features of the brain and related structures in staged human embryos during the sixth week of development. Am J Anat 180:69-86.

Orentas DM, Miller RH (1996) A novel form of migration of glial precursors. Glia 16:27-39.

Orentas DM, Hayes JE, Dyer KL, Miller RH (1999) Sonic hedgehog signaling is required during the appearance of spinal cord oligodendrocyte precursors. Development 126:2419-2429.

Pfeiffer SE, Warrington AE, Bansal R (1993) The oligodendrocyte and its many cellular processes. Trends Cell Biol 3:191-197.

Rakic S, Zecevic N (2003) Early oligodendrocyte progenitor cells in the human fetal telencephalon. Glia 41:117-127.

Rao MS, Noble M, Mayer-Proschel M (1998) A tripotential glial precursor cell is present in the developing spinal cord. Proc Natl Acad Sci USA 95:3996-4001.

Richardson WD, Pringle NP, Yu WP, Hall AC (1997) Origins of spinal cord oligodendrocytes: possible developmental and evolutionary relationships with motor neurons. Dev Neurosci 19:58-68.

Richardson WD, Smith HK, Sun T, Pringle NP, Hall A, Woodruff R (2000) Oligodendrocyte lineage and the motor neuron connection. Glia 29:136-142.

Rivkin MJ, Flax J, Mozell R, Osathanondh R, Volpe JJ, Villa-Komaroff L (1995) Oligodendroglial development in human fetal cerebrum. Ann Neurol 38:92-101.

Rowitch DH (2004) Glial specification in the vertebrate neural tube. Nat Rev Neurosci 5:409-419.

Rowitch DH, Lu QR, Kessaris N, Richardson WD (2002) An "oligarchy" rules neural development. Trends Neurosci 25:417-422.

Sidman RL, Rakic P (1982) Development of the human central nervous system. Springfield, IL: C. C. Thomas.

Sommer I, Schachner M (1981) Monoclonal antibodies (O1 to O4) to oligodendrocyte cell surfaces: an immunocytological study in the central nervous system. Dev Biol 83:311-327.

Spassky N, Goujet-Zalc C, Parmantier E, Olivier C, Martinez S, Ivanova A, Ikenaka K, Macklin W, Cerruti I, Zalc B, Thomas JL (1998) Multiple restricted origin of oligodendrocytes. J Neurosci 18:8331-8343.

Spassky N, Olivier C, Perez-Villegas E, Goujet-Zalc C, Martinez S, Thomas J, Zalc B (2000) Single or multiple oligodendroglial lineages: a controversy. Glia 29:143-148.

Stallcup WB, Beasley L (1987) Bipotential glial precursor cells of the optic nerve express NG2 proteoglycan. J Neurosci 7:2737-2744.

Sussel L, Marin O, Kimura S, Rubenstein JL (1999) Loss of Nkx2.1 homeobox gene function results in a ventral to dorsal molecular respecification within the basal telencephalon: evidence for a transformation of the pallidum into the striatum. Development 126:3359-3370.

Takebayashi H, Yoshida S, Sugimori M, Kosako H, Kominami R, Nakafuku M, Nabeshima Y (2000) Dynamic expression of basic helix-loop-helix Olig family members: implication of Olig2 in neuron and oligodendrocyte differentiation and identification of a new member, Olig3. Mech Dev 99:143-148.

Takebayashi H, Nabeshima Y, Yoshida S, Chisaka O, Ikenaka K, Nabeshima Y-C (2002) The basic helix-loop-helix factor olig2 is essential for the development of motoneuron and oligodendrocyte lineages. Curr Biol 12:1157-1163.

Tekki-Kessaris N, Woodruff R, Hall AC, Gaffield W, Kimura S, Stiles CD, Rowitch DH, Richardson WD (2001) Hedgehog-dependent oligodendrocyte lineage specification in the telencephalon. Development 128:2545-2554

Timsit SG, Bally-Cuif L, Colman DR, Zalc B (1992) DM-20 mRNA is expressed during the embryonic development of the nervous system of the mouse. J Neurochem 58:1172-1175.

Ulfig N, Briese M, Bohl J (2002) Expression of oligodendrocyte-specific protein (OSP/claudin-11) in the human fetal forebrain. Neuroembryology 1:48-53.

Vallstedt A, Klos JM, Ericson J (2005) Multiple dorsoventral origins of oligodendrocyte generation in the spinal cord and hindbrain. Neuron 45:55-67.

Weidenheim KM, Kress Y, Epshteyn I, Rashbaum WK, Lyman WD (1992) Early myelination in the human fetal lumbosacral spinal cord: characterization by light and electron microscopy. J Neuropathol Exp Neurol 51:142-149.

Xin M, Yue T, Wu FF, Gow A, Lu QR (2005) Myelogenesis and axonal recognition by oligodendrocytes in brain are uncoupled in Olig-1 null mice. J Neurosci 25:1354-1365.

Zhou Q, Anderson DJ (2002) The bHLH transcription factors olig2 and olig1 couple neuronal and glial subtype specification. Cell 109:61-73.

Zhou Q, Wang S, Anderson DJ (2000) Identification of a novel family of oligodendrocyte lineage-specific basic helix-loop-helix transcription factors. Neuron 25:331-343.

Zhou Q, Choi G, Anderson DJ (2001) The bHLH transcription factor Olig2 promotes oligodendrocyte differentiation in collaboration with $\mathrm{Nkx2.2}$ Neuron 31:791-807. 